States for the supply of enriched uranium. The United States maintains that India should sign the Nuclear Non-Proliferation Treaty and open all its nuclear installations - indigenous as well as foreign-aided for international inspection as required by the US Nuclear Non-Proliferation Act of 1978. The supposed fear is that a uranium reprocessing facility in India might be used to extract plutonium for atomic weapons.

India rejects this contention, however, arguing that the 1978 US legislation should not be applied retrospectively and unilaterally to a bilateral agreement entered into in 1963. India has said time and time again that its nuclear technology would be used for peaceful purposes only. India holds the Nuclear Non-Proliferation Treaty to be discriminatory, saying it includes only civilian establishments and specifically excludes military establishments of the nuclear weapon states which prescribe non-proliferation for others and not for themselves.

The issue is now a matter of principle especially as India is now almost selfreliant for nuclear fuel production.

Indian nuclear scientists have developed mixed oxide fuel of uranium and plutonium which can work as alternative fuel in place of the enriched uranium supplied by the United States for the Tarapur plant. The only other operational nuclear power plant at Kota in Rajasthan utilizes indigenous natural uranium. The nuclear plants being built at Narora and Kalpakkam will also be pressurized heavy water reactors using indigenous uranium.

Sunil Saraf

\section{US nuclear technology Exports raise fears}

\section{Washington}

Fears are mounting in Washington that the Administration's efforts to increase nuclear technology exports could be encouraging the proliferation of nuclear weapons. Last Thursday, members of Congress questioned the Administration closely about its agreement with Australia which, for the first time, would mean the United States sharing its knowledge of centrifuge technology for enriching uranium.

The criticism came only a few days after a new storm had broken over the ability of the International Atomic Energy Agency (IAEA) in Vienna to provide satisfactory safeguards against the diversion of nuclear materials from civilian to military use.

The decision to share enrichment technology with Australia is part of an effort to encourage US companies to participate in a joint venture with the Australian government to construct enrichment facilities for its nuclear industry. It was contained in a memorandum signed on 12 November by President Reagan which also instructed the Department of Energy to look at ways of

\title{
British academics at the barricades
}

Genteel academic militancy reached boiling point last week, with a mass lobby of the British Parliament by some 10,000 university teachers protesting not merely at the British government's decision that the university budget should be cut but at the uncertainty.that remains about the arrangements that may (or may not) be made to deal with redundancies among academics. Some of the participants (see picture) wore fancy dress.

The lobby (on Wednesday, 18 November) coincided with a debate in the House of Commons on the planned reduction of the public subvention for universities, called by the Labour

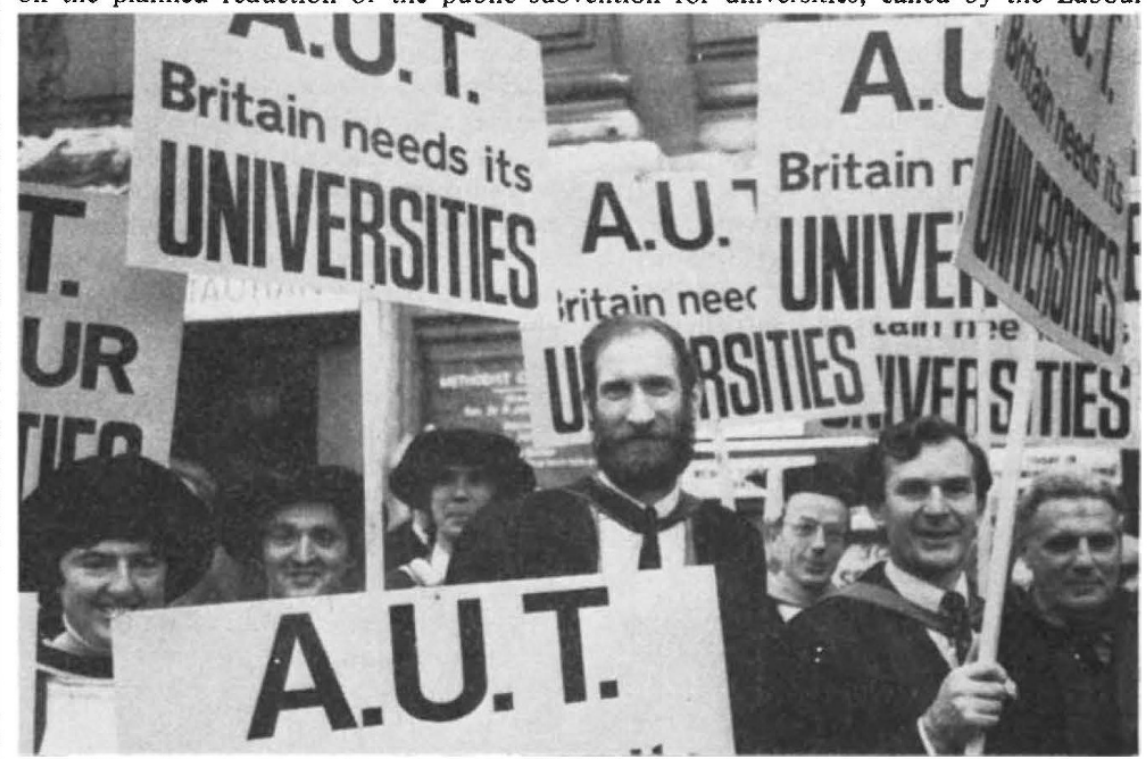

opposition. One government speaker complained that it would have been more convenient if the debate had been arranged for the following day, so that those inclined to do so would have had a chance to listen to what the lobbyists were saying.

Both occasions followed by a lunch-time break the first appearance of Sir Keith Joseph, the new (since last month) Secretary of State for Education and Science, before the Select Committee on Education, at which he and his retinue of civil servants were unable to put into words a definition of the "Robbins principle", the doctrine that qualified candidates for university entry should be catered for. At the beginning of last week, the UK Committee of Vice-Chancellors also (unusually) made public its own account of an unsatisfactory meeting with the minister and a waspish letter it had written to him afterwards.

The debate in the House of Commons has confused and not clarified the immediate financial prospects of British universities. Sir Keith Joseph and his minister with special responsibility for higher education, Mr William Waldegrave, declined to answer the apparently simple question whether the government would pay the cost to universities of breaking contracts with tenured academics. Each of them said, however, that the British government would be prepared to "listen to" arguments that it would save money by extending the period over which the universities were now required to contract.

The Committee of Vice-Chancellors is now drafting such a document.

transferring the federal uranium enrichment programme into private hands.

During a hearing of the Senate Foreign Relations Committee's subcommittee on energy and nuclear non-proliferation, several members questioned Administration officials closely on this decision. Centrifuge technology has previously been subject to strong government restrictions, on the grounds that it could provide a relatively inexpensive way of producing weaponsgrade nuclear fuel.

However, the Administration continues to insist that, although a hard line will be taken with any country that diverts civilian technology to military use, in general IAEA provides the best way of minimizing the risks of proliferation through its safeguards and regular inspections.

This argument suffered a setback earlier this year when an ex-lAEA inspector, $\mathrm{Mr}$ Roger Richter, told the same Senate committee that IAEA had failed to detect efforts by the Iraqi government to work clandestinely on nuclear weapons, and that present IAEA safeguards were "totally incapable of detecting the production of plutonium in large-size material test reactors".

At the time, IAEA officials fiercely contested Mr Richter's conclusions, claiming that he had not been aware of all the relevant facts. However, it now looks as if they will have to go through the same process in defending themselves against criticisms made by another ex-inspector, $\mathrm{Mr}$ Emanuel R. Morgan, in a report commissioned for the Nuclear Regulatory Commission by commissioner $\mathrm{Mr}$ Victor Gilinsky.

The report - not of ficially released but leaked to the New York Times - echoes Mr Richter's conclusion that IAEA is incapable of detecting the diversion of a significant quantity of nuclear fuel "in any state with a moderate to large nuclear energy establishment". 
This memorandum, likely to be discussed shortly in a congressional hearing, is the first critical assessment of IAEA's safeguards to have been prepared for a federal agency. The State Department issued a statement saying that although it accepted that the safeguards system was not perfect, there was "simply no alternative to an international safeguards regime'.

David Dickson

\section{Product development}

\section{British battle on}

\section{Brussels}

The British government is fighting hard to exclude development risks from the EEC's draft directive on product liability now being debated in Coreper - the Committee of Permanent Representatives to the European Community. This has caused great consternation among the European consumer lobby group, Beuc. The consumer group fears that the exclusion of development risks would undermine the whole system of direct liability, by reversing the burden of proof and placing it on the consumer.

The alternative to development risks, the state-of-the-art defence, means that if the manufacturer can prove that he took all reasonable care in the light of the state of scientific and technical development to ensure that his product was safe, he avoids paying compensation. But who then compensates the consumer for his loss if a product, such as thalidomide, turns out to be dangerous? In the United Kingdom the Pearson Royal Commission and the Law Society, concluded that the manufacturer should bear direct liability for development risks. The Council of Europe has come to the same conclusion and France, Belgium and Luxembourg have signed a convention to that effect.

Belgium takes over the presidency of the Council of Ministers from Britain next year and the United Kingdom is anxious to have this part of the directive dealt with by then. The British argue, following pressure from the pharmaceutical industry, that development risks inhibit innovation and competitivity. In the last debate on this subject in the House of Commons, Sally Oppenheimer, the Minister for Consumer Affairs, argued that the EEC proposals would involve a major change for British manufacturers.

The experience in other EEC countries shows that the change is not as painful as alleged. For instance, the German law on pharmaceutical products provides for direct liability and manufacturers cover themselves by taking out an insurance amounting to 2 per cent of turnover.

The British are, however, confident that a compromise can be reached. This could involve excluding development risks or limiting them to pharmaceutical products.

Jasper Becker
US solar energy

\section{Golden housing}

\section{Washington}

Denying charges that the Reagan Administration is ideologically biased against solar energy in favour of nuclear, US Energy Secretary Mr James Edwards last week announced the go-ahead for the Solar Energy Research Institute (SERI) in Golden, Colorado, to start building a permanent research and test facility.

The Administration's decision is its first bit of good news for supporters of solar energy, whose budget within the Department of Energy has dropped from the $\$ 707$ million proposed by President Carter to less than half that in the current year.

Much of this reduction in funds had been felt at SERI. This institute, which is run for the Department of Energy by the Midwest Research Institute, has already had its budget cut from $\$ 120$ million to $\$ 50$ million, and staff reduced from 960 to 650 .

Since its creation in 1977, SERI has occupied temporary premises in the town of Golden, just outside Denver, Colorado. But it has also been planning a combined laboratory and showcase, to be located on a nearby mesa on land donated by the state.

Initial proposals for a solar research and demonstration centre costing \$124 million were reduced by the Carter Administration, which then requested $\$ 24$ million in the 1981 budget for the first stage of construction. One of the first acts of the Reagan Administration was to withhold all construction money on the grounds that it was re-evaluating its whole approach towards funding solar energy research.

At one point, it was rumoured that the Office of Management and Budget was contemplating eliminating all funding for such research from the Department of Energy's budget. Publicly, however, the Administration has stated that although it is eliminating demonstration projects which it feels ought to be supported by the private sector - if at all - it accepts the need for federal support of long-range, high risk research.

The permission from the Department of Energy for construction of SERI's laboratory is being used by the Administration to symbolize a commitment to solar power. But Mr Edwards said that the $\$ 9.5$ million which he was making available for the initial construction phase - money from appropriations previously authorized by Congress - did not necessarily mean extra funds for energy research.

But the decision to fund SERI's laboratory does not necessarily mean that federal support for solar energy research will be generous. The rumour in Washington is that the Department of Energy's budget request for 1983 contains a meagre $\$ 93$ million for all solar energy work, a contraction to the level of the early 1970s.
Californian Medflies

\section{Innocent victims}

\section{Palo Alto, California}

If aerial spraying with the insecticide malathion is used to counter the threat of Mediterranean fruit fly in California this winter, an unexpected casualty might be one of the oldest continuously studied insect populations in the world.

Jasper Ridge is a 1,200-acre natural wilderness to the west of the Stanford University campus in California, between suburban San Jose and the city of San Francisco. More than 120 dissertations and papers have been written about the area since 1897 when studies began in earnest. So far, Jasper Ridge has been a virtually unsprayed island, surrounded by a 600 -foot buffer zone. But in July spraying began in areas next to the reserve.

Most immediately at risk, of course, are the insects themselves, notably the checkerspot butterfly Euphydryas editha, which has been the subject of a continuous population study since 1960, under Professor Paul Ehrlich.

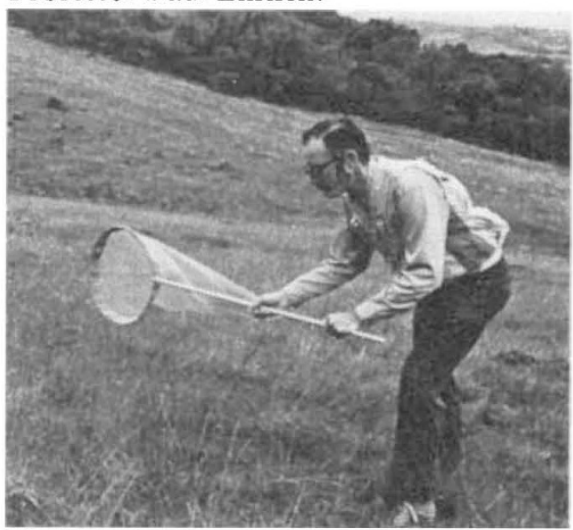

Paul Ehrlich may search in vain next year

Although Jasper Ridge has not been sprayed directly, minute droplets of malathion bait $(20-40 \mu \mathrm{m})$ have been found on plant leaves within the reserve, and these droplets must have drifted into the area from nearby spraying operations. During the summer, the drifting droplets did not appear to affect the checkerspot butterflies, which lay dormant under ground. But in the rainy season the checkerspots emerge to feed, and any direct spraying during the winter would almost certainly mean their complete disappearence from Jasper Ridge. Aerial spraying has been curtailed for the winter months, but will be stepped up again next spring (see Nature 12 November, p.103).

Direct spraying would almost certainly be carried out, however, if two adult Medflies, or a pupa, were found within the Jasper Ridge reserve. The ecological balance of the reserve would then be irretrievably disturbed by an uncontrollable variable. Donald Kennedy, a biologist and Stanford University president, compares the possible loss of Jasper Ridge with the loss of an irreplaceable library. Charlotte K. Beyers 